\title{
Rhinolith causing unilateral chronic maxillary rhinosinusitis
}

\author{
Kiran Varadharajan, ${ }^{1}$ Joanna Stephens, ${ }^{1}$ Gitta Madani, ${ }^{2}$ Abhijeet Parikh ${ }^{1}$
}

'Department of ENT, St Mary's Hospital, London, UK

${ }^{2}$ Department of Radiology, St Mary's Hospital, London, UK

Correspondence to Kiran Varadharajan, kiranvarad@doctors.org.uk

Accepted 21 March 2014

\section{DESCRIPTION}

A 58-year-old man presented to our otolaryngology clinic with a 4-year history of chronic right-sided nasal obstruction associated with hyposmia and occasional nasal discharge. The symptoms had been managed in the community with nasal steroids.

However, he continued to have persistent nasal obstruction affecting his daily quality of life.

Flexible nasendoscopy revealed a right-sided unilateral nasal mass. A CT of the sinuses (figure 1) showed a large calcified nasal body extending along the floor of the nose, consistent with a rhinolith. Although the rhinolith did not involve the anterior ostiomeatal unit and the middle meatus was normally aerated, the maxillary sinus was opacified consistent with maxillary sinusitis.

Examination under anaesthesia revealed a rhinolith along the floor of the nose (figure 2). In addition a maxillary antrostomy demonstrated pus in the right maxillary sinus consistent with concomitant right maxillary chronic rhinosinusitis. The rhinolith was removed and maxillary sinus irrigated. Histology demonstrated acellular calcified debris with no foreign body material consistent with an endogenous rhinolith. The patient reported a significant improvement in his symptoms postoperatively.

Rhinoliths are rare calcified masses that form in the nose. They can present with unilateral nasal

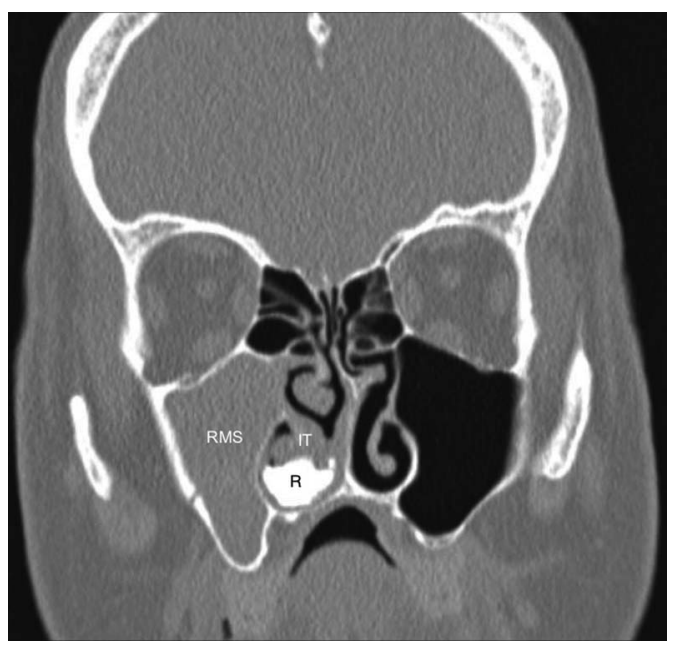

Figure 1 Coronal view of a CT scan demonstrating the rhinolith in the floor of the nose and unilateral maxillary rhinosinusitis (RMS, right maxillary sinus; IT, inferior turbinate; $R$, rhinolith).

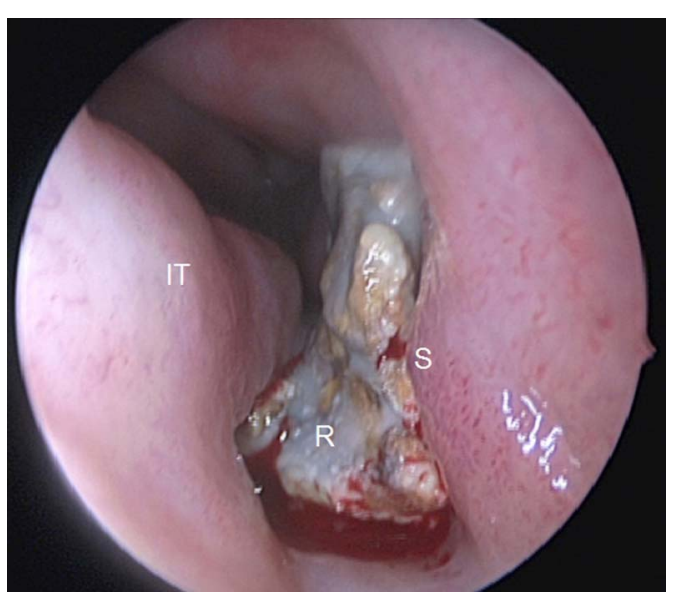

Figure 2 Endoscopic view of the rhinolith in the right inferior meatus ( $R$, rhinolith; IT, inferior turbinate; S, septum).

obstruction $^{1}$ or incidentally. ${ }^{2}$ Our case illustrates a rhinolith which caused ipsilateral maxillary sinusitis, without physically obstructing the anterior ostiomeatal unit. It is important to urgently investigate cases of unilateral nasal obstruction with CT scanning and formal endoscopic assessment to rule out a malignancy.

\section{Learning points}

- Unilateral nasal masses must be investigated with CT scanning and examination under anaesthesia to exclude malignancy.

- Rhinoliths are a rare phenomenon and can result in unilateral chronic rhinosinusitis.

Competing interests None.

Patient consent Obtained.

Provenance and peer review Not commissioned; externally peer reviewed.

\section{REFERENCES}

1 Brehmer D, Riemann R. The rhinolith-a possible differential diagnosis of a unilateral nasal obstruction. Case Rep Med 2010;2010:845671

2 Kermanshahi MS, Jassar P. A bolt from the blew: rhinolith in the nose for more than 80 years. BMJ Case Rep Published online: 27 Nov 2012. doi:10.1136/bcr-2012-007322 
Copyright 2014 BMJ Publishing Group. All rights reserved. For permission to reuse any of this content visit http://group.bmj.com/group/rights-licensing/permissions.

BMJ Case Report Fellows may re-use this article for personal use and teaching without any further permission.

Become a Fellow of BMJ Case Reports today and you can:

- Submit as many cases as you like

- Enjoy fast sympathetic peer review and rapid publication of accepted articles

- Access all the published articles

- Re-use any of the published material for personal use and teaching without further permission

For information on Institutional Fellowships contact consortiasales@bmjgroup.com

Visit casereports.bmj.com for more articles like this and to become a Fellow 